PEDAGOGI: JURNAL PENDIDIKAN DASAR

http://jurnal.fkip.unila.ac.id/index.php/pgsd

\title{
Pengaruh Penerapan Model Problem Based Learning Berbantuan Media Audio Visual Terhadap Hasil Belajar Tematik Peserta Didik Kelas IV SD Negeri 1 Sumberagung
}

\author{
Istikomatin Napsiah, Muncarno Muncarno, Ujang Efendi \\ PGSD, Universitas Lampung \\ Jl. Prof. Dr. Soemantri Brojonegoro No.1, Bandar Lampung
}

\begin{abstract}
The purpose of the study was to determine whether there was an effect of applying the problem based learning model with the aid of audio-visual media on the learning outcomes of students in elementary schools. This research is quantitative research with Quasi Experimental Design method with Nonequivalent Control Group Design. The population in this study were fourth grade students at SD Negeri 1 Sumberagung, totaling 48 students. This research used purposive sampling technique. Data collection techniques used tests and observations. Data analysis techniques used a simple linear regression formula. Based on the results of the study, it can be stated that there is an influence on the application of problem based learning models assisted by audio visual media on thematic learning outcomes of fourth grade students of SD Negeri 1 Sumberagung. The results of this study are expected to be a reference for educators to innovate in developing innovative learning.
\end{abstract}

Keywords: Problem based learning, audio visual media, learning outcomes

\begin{abstract}
Abstrak: Tujuan penelitian adalah untuk mengetahui apakah terdapat pengaruh penerapan model problem based learning berbantuan media audio visual terhadap hasil belajar peserta didik di sekolah dasar. Penelitian ini adalah penelitian kuantitatif dengan metode Quasi Experimental Design dengan Nonequivalent Control Group Design. Populasi dalam penelitian ini adalah peserta didik kelas IV di SD Negeri 1 Sumberagung yang berjumlah 48 peserta didik. Penelitian ini menggunakan teknik purposive sampling. Teknik pengumpulan data menggunakan tes dan observasi. Teknik analisis data menggunakan rumus regresi linier sederhana. Berdasarkan hasil penelitian, dapat dinyatakan bahwa terdapat pengaruh pada penerapan model problem based learning berbantuan media audio visual terhadap hasil belajar tematik peserta didik kelas IV SD Negeri 1 Sumberagung. Hasil penelitian ini diharapkan dapat menjadi referensi bagi pendidik untuk melakukan inovasi dalam mengembangkan pembelajaran yang inovatif.
\end{abstract}

Kata Kunci: Problem based learning, media audio visual, hasil belajar 


\section{PENDAHULUAN}

Pendidikan memegang peranan penting dalam mencerdaskan kehidupan bangsa, oleh karena itu setiap individu yang terlibat dalam pendidikan dituntut berperan serta secara maksimal guna meningkatkan mutu pendidikan tersebut, pada UU No. 20 Tahun 2003 bab 1 pasal 1 ayat 1 tentang Depdiknas dinyatakan sebagai berikut:

"Pendidikan adalah usaha sadar dan terencana untuk mewujudkan suasana belajar dan proses pembelajaran agar peserta didik secara aktif mengembangkan potensi dirinya untuk memiliki kekuatan spiritual keagamaan, pengendalian diri, kepribadian, kecerdasan, akhlak mulia, serta keterampilan yang diperlukan dirinya, masyarakat, bangsa, dan negara.

Berdasarkan Undang-undang yang telah dipaparkan di atas, tujuan dari pendidikan di Indonesia adalah untuk mewujudkan suasana belajar dan proses pembelajaran aktif agar peserta didik dapat mengembangkan potensi yang dimiliki, salah satunya pemilihan model dan metode serta media pembelajaran yang sesuai dengan tujuan pembelajaran. Model pembelajaran yang dianggap mampu meningkatkan kemampuan peserta didik salah satunya yaitu Model Problem Based Learning. Pengertian Model Problem Based Learning adalah metode belajar yang menggunakan masalah sebagai langkah awal dalam mengumpulkan dan mengintegrasikan pengetahuan baru (Ali Muhson, 2009). Selain itu, didukung oleh pendapat (Syahroni Ejin, 2016) yang menyatakan bahwa Problem Based Learning adalah model pembelajaran dimana peserta didik dihadapkan pada masalah kehidupan nyata (kontekstual) dari lingkungan sehingga dapat meningkatkan kemampuan pemahaman konsep dan dan berpikir kritis peserta didik.

Guna membantu pelaksanaan model pembelajaran, suatu pembelajaran juga didukung oleh penggunaan media untuk memudahkan peserta didik dalam memahami materi yang diajarkan. Media yang digunakan dalam pembelajaran agar lebih bermakna bagi peserta didik yaitu media audio visual. Melalui media pembelajaran audio visual peserta didik ditampilkan tayangan-tayangan nyata 
berupa film pendek tentang materi yang di pelajari. Media audio visual merupakan media pembelajaran yang dapat dilihat dan didengar dalam satu proses atau kegiatan.

Berdasarkan observasi penelitian pendahuluan yang dilakukan pada bulan Januari 2021 di SD Negeri 1 Sumberagung Kec. Ambarawa Kab. Pringsewu diperoleh informasi menyatakan bahwa hasil belajar peserta didik berdasarkan nilai ujian semester ganjil tahun pelajaran 2020/2021 kelas IV tergolong rendah. hal tersebut dapat dilihat dari Kriteria Ketuntasan Minimal (KKM) yang telah ditetapkan yaitu 70. Adapun dari 48 peserta didik di seluruh kelas IV, dikelas IVA sendiri 11 peserta didik atau 45,8\% yang mendapatkan nilai diatas KKM sedangkan yang mendapat nilai dibawah KKM sebanyak 13 peserta didik atau 54,1\% dan dikelas IVB sendiri 9 peserta didik atau 37,5\% yang mendapatkan nilai diatas KKM sedangkan yang mendapat nilai dibawah KKM sebanyak 15 peserta didik atau $62,5 \%$. Dengan demikian masih harus dicari alternatife untuk meningkatkan hasil belajar peserta didik.

Rendahnya hasil belajar di sekolah diduga karena kurangnya variasi model pembelajaran yang digunakan oleh pendidik sehingga peserta didik menjadi lebih cepat bosan, pembelajaran masih berpusat pada pendidik, dan pendidik belum menerapkan atau menggunakan media pembelajaran. Media pembelajaran yang digunakan harus sesuai dengan materi, pendidik belum maksimal dalam menerapkan model pembelajaran yang menarik untuk menstimulus peserta didik aktif dan berpikir kritis dalam proses pembelajaran, dan peserta didik kurang memahami materi yang telah disampaikan oleh pendidik hal ini tersebut disebabkan karena banyak peserta didik yang masih banyak mengobrol dengan temannya dan hanya beberapa yang mendengarkan penjelasan dari pendidik.

Berdasarkan permasalahan di atas, diperlukan solusi yang dapat digunakan untuk memperbaiki hasil belajar peserta didik. Salah satu cara yang dapat digunakan untuk meningkatkan nilai hasil belajar peserta didik yaitu pendidik harus mampu 
memilih dan memvariasi model pembelajaran agar peserta didik dapat dengan mudah menerima materi pelajaran sehingga peserta didik tidak mudah merasa bosan dalam proses pembelajaran dengan begitu peserta didik lebih aktif dalam mengikuti pembelajaran serta mendapatkan hasil belajar yang lebih baik. Nilai hasil belajar peserta didik dapat dipakai untuk menilai keberhasilan proses pembelajaran di sekolah dan juga mengukur kinerja pendidik dalam melaksanakan proses pembelajaran. Penelitian ini bertujuan untuk mengetahui apakah terdapat pengaruh penerapan model problem based learning berbantuan media audio visual terhadap hasil belajar peserta didik di SD Negeri 1 Sumberagung Pringsewu.

\section{METODE}

Jenis penelitian ini adalah penelitian kuantitatif dengan metode Quasi Experimental Design. Desain eksperimen pada penelitian ini adalah Nonequivalent Control Group Design yaitu kegiatan penelitian yang terbagi menjadi dua kelompok kelas dimana satu kelas menjadi kelas non eksperimen dan kelas lainnya menjadi kelas eksperimen yang tidak dipilih secara random. Penelitian ini dilaksanakan pada tahun ajaran 2020/2021 di kelas IV SD Negeri 1 Sumberagung Pringsewu. Penelitian ini dilaksanakan di kelas IVA sebagai kelas non eksperimen dan kelas IVB sebagai kelas eksperimen.

Populasi dalam penelitian ini adalah peserta didik kelas IV di SD Negeri 1 Sumberagung yang berjumlah 48 peserta didik. Penelitian ini menggunakan teknik purposive sampling atau sampel berdasarkan tujuan penelitian. Teknik pengumpulan data yang digunakan yaitu teknik tes dan observasi. Variabel dalam penelitian terdiri dari variabel bebas yaitu model problem based learning berbantuan media audio visual $(\mathrm{X})$, sedangkan variabel terikat yaitu hasil belajar tematik (Y). Teknik analisis data untuk mengetahui pengaruh antar variabel $\mathrm{X}$ dan variabel Y menggunakan rumus regresi linier sederhana dengan kriteria jika $\mathrm{F}_{\text {hitung }}>\mathrm{F}_{\text {tabel }}$ maka $\mathrm{H}_{\mathrm{o}}$ ditolak dan $\mathrm{H}_{\mathrm{a}}$ diterima dan jika $\mathrm{F}_{\text {hitung }}<\mathrm{F}_{\text {tabel }}$ maka $\mathrm{H}_{\mathrm{o}}$ diterima dan $\mathrm{H}_{\mathrm{a}}$ ditolak dengan mengambil taraf signifikansi $5 \%$. 


\section{HASIL DAN PEMBAHASAN}

Penelitian ini diawali dengan observasi pada bulan januari 2021 di SD Negeri 1 Sumberagung. Setelah mendapatkan data penelitian pendahuluan, peneliti membuat soal pretest dan posttest untuk mendapatkan data. Setelah itu, soal tersebut diuji cobakan dengan 22 peserta didik kelas IVC SD Negeri 1 Ambarawa pada tanggal 21 Mei 2021. Peneliti membagikan soal secara langsung kepada responden. Penelitian dilaksanakan di SD Negeri 1 Sumberagung dengan memberikan soal pretest dan posttest kepada responden sebanyak 48 peserta didik. Pengumpulan data dilaksanakan di SD Negeri 1 Sumberagung Pringsewu pada tanggal 24-29 Mei 2021 di kelas IVA dan IVB. Materi yang disampaikan pada saat penelitian merupakan Tema 7 (Indahnya Keragaman di Negeriku) Subtema 2 (Indahnya Keragaman Budaya Negeriku) Pembelajaran 1-3. Soal dikerjakan peserta didik di sekolah. Pengambilan data dilakukan sebanyak 2 kali kepada seluruh populasi dalam penelitian dengan mengerjakan soal pretest dan posttest. Mengetahui ketercapaian model problem based learning berbantuan media audio visual peneliti menggunakan nilai pretest dan posttest. Kelas IVA berperan sebagai kelas non eksperimen sedangkan kelas IVB merupakan kelas eksperimen, penelitian dilakukan di kelas IVB yang dijadikan sampel berjumlah 24 peserta didik.

Berdasarkan hasil penelitian, diperoleh nilai rata-rata hasil belajar peserta didik kelas eksperimen (IVB) yaitu 76,5\% lebih tinggi dari nilai rata-rata hasil belajar peserta didik pada kelas non eksperimen (IVA), yaitu 71,8\% dilihat dari mengerjakan soal pretest dan posttest. Uji coba instrumen pada penelitian ini menggunakan validitas dengan rumus product moment dan reliabilitas menggunakan rumus cronbach alpha. Setelah diketahui rata-rata nilai pretest dan posttest kedua kelas, selanjutnya menghitung peningkatan hasil belajar peserta didik setelah diberi perlakuan dengan menggunakan rumus $N$-Gain. Hasil perhitungan rata-rata nilai $\mathrm{N}$-Gain setelah diterapkan Model Problem Based Learning berbantuan media audio visual pada kelas eksperimen memiliki nilai $N$ - 
Gain lebih besar dari pada kelas non eksperimen. Nilai $N$-Gain untuk kelas eksperimen sebesar 0,43 dan kelas non eksperimen 0,30. Keduanya masuk dalam kategori sedang. Selisih nilai $\mathrm{N}$-Gain kelas eksperimen dan kelas non eksperimen adalah sebesar 0,13 . Uji prasyarat analisis data pada penelitian ini menggunakan uji normalitas data dengan rumus menggunakan kolmogorov-smirnov test dan uji homogenitas menggunakan rumus uji-F. Berdasarkan hasil perhitungan uji hipotesis menggunakan rumus regresi linier sederhana didapatkan bahwa $F_{h i t u n g}>$ $\mathrm{F}_{\text {tabel }}=$ atau 12,116> 2,05 maka tolak Ho artinya signifikan. Karena $F_{\text {hitung lebih }}$

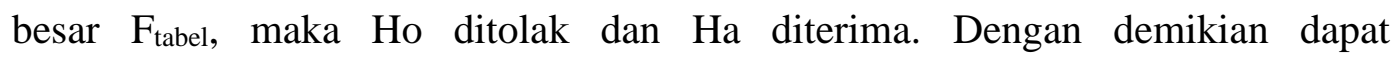
disimpulkan bahwa terdapat pengaruh yang signifikan antara Model Problem Based Learning berbantuan media audio visual terhadap hasil belajar tematik peserta didik kelas IV SD Negeri 1 Sumberagung.

Hasil penelitian ini relevan dengan penelitian Dyah Aini, Nyoman Dantes, Putu Budi (2018) Buleleng, Bali. Dengan judul 'Pengaruh Problem Based Learning Berbantuan Media Audio Visual Terhadap Kemampuan Berpikir Kritis dan Hasil Belajar IPA di Sekolah Dasar"' Jurnal Pendidikan Dasar Indonesia. Vol.2 No.1. Hasil penelitian ini menunjukkan bahwa terdapat pengaruh pendekatan saintifik berbasis Problem Based Learning berbantuan media audio visual terhadap hasil belajar IPA pada peserta didik kelas III di sekolah dasar. Persamaan sekaligus dan yang menjadi acuan pada penelitian ini yaitu variabel bebas problem based learning dan variabel terikat hasil belajar, jenis penelitian eksperimen semu, teknik pengumpulan data hasil belajar berupa soal pilihan ganda. Kemudian penelitian Atika Roudhotul, Intan Rahmawati, Fine Reffiane (2020).Semarang.' Keefektifan Model PBL Berbantu Media Audio Visual Terhadap Hasil Belajar Tema Indahnya Keragaman di Negeriku', hasil penelitian ini menunjukkan melalui penerapan Model Problem Based Learning berbantu media audio visual dapat meningkatkan hasil belajar peserta didik. Persamaan sekaligus dan yang menjadi acuan pada penelitian ini yaitu variabel bebas PBL berbantu media audio visual, jenis penelitian kuantitatif dalam bentuk PreExperimental Design dengan desain One-Group Pretest-Posttest Design, teknik 
pengumpulan data menggunakan soal pretest-posttest, sampel yang diambil menggunakan teknik Nonprobability Sampling.

Selanjutnya penelitian I Made Dwi Paramartha, dkk (2016) berjudul 'Pengaruh Model PBL Berbantuan Media Audio Visual Terhadap Penguasaan Kompetensi Pengetahuan IPA" hasil penelitian ini yaitu nilai rata-rata menunjukkan bahwa penguasaan kompetensi pengetahuan IPA kelompok peserta didik yang dibelajarkan menggunakan Model Problem Based Learning berbantuan media audio visual $\overline{\mathrm{X}}=81,12>68,63$ rata-rata penguasaan kompetensi pengetahuan IPA kelompok peserta didik yang dibelajarkan secara konvensional. Dengan demikian dapat disimpulkan bahwa Model Problem Based Learning berbantuan media audio visual berpengaruh terhadap penguasaan kompetensi pengetahuan IPA peserta didik kelas IV SD Gugus Pangeran Diponegoro. Dan penelitian Umainalo, dkk. (2019) Problem Based Learning As An Effort To Improve Student Learning Aoutcomes. This can be seen at the average value of students befor the use of problem based learning (pretest) is 58.80 and the value after problem based learning (posttest) ist 89.30.

Hasil analisis data menunjukkan bahwa nilai rata-rata peserta didik mengalami peningkatan setelah diberikan pembelajaran menggunakan model problem based learning berbantuan media audio visual. Hal ini menunjukkan bahwa penerapan model problem based learning berbantuan media audio visual mampu melatih peserta didik secara aktif dalam pembelajaran serta tidak mudah melupakan materi yang telah dipelajari dan untuk mengembangkan segala pengetahuan yang dimilikinya. Hal ini sejalan dengan pendapat Hikmi, dkk. (2018:290) model problem based learning tidak hanya pemecahan masalah tetapi juga sebuah pedagogik yang berdasarkan konstruktivisme dengan masalah-masalah nyata yang didesain belajar dengan lingkungan sekitarnya dimana ada proses penemuan (inkuiri), belajar mandiri, memperoses informasi, diskusi, dan diorganisasikan dengan pembelajaran sebelumnya. Menurut Susanto (2013:5) "Hasil belajar adalah perubahan-perubahan yang terjadi pada diri peserta didik, baik yang menyangkut aspek kognitif, afektif, dan psikomotor sebagai hasil dari kegiatan 
belajar".

Penelitian ini akan menggunakan teori konstruktivistik karena teori kontruktivistik sendiri merupakan sebuah teori yang melibatkan peserta didik secara langsung untuk membangun pengetahuannya sendiri. Model ini berpengaruh untuk peserta didik secara langsung dalam membangun pengetahuannya sendiri. Hal ini selaras dengan penggunaan model problem based learning dimana peserta didik berusaha untuk menemukan sendiri pengetahuannya dan membangun sendiri pengetahuannya selaras dengan pendapat Piaget dalam Budiningsih Asri (2012: 58), belajar merupakan suatu proses pembentukan pengetahuan.

Hasil penelitian ini menunjukkan perbedaan antara hasil belajar peserta didik yang diajarkan menggunakan model problem based learning dengan hasil belajar peserta didik menggunakan model discovery learning. hal ini menunjukkan bahwa penerapan model problem based learning berbantuan media audio visual mampu melatih secara aktif dalam pembelajaran serta tidak mudah melupakan materi yang telah dipelajari dan untuk mengembangkan segala pengetahuan yang dimilikinya. Adanya pengaruh pada peningkatan hasil belajar membuktikan bahwa terjadi perubahan pada individu yang belajar, sebagai tingkat keberhasilan peserta didik dalam materi pembelajaran di sekolah yang didasarkan atas tujuan pembelajaran yang ditetapkan.

Data hasil belajar pretest dan posttest yang menggunakan model problem based learning berbantuan media audio visual yang dilakukan peneliti diperoleh hasil perhitungan yang menyatakan bahwa pembelajaran menggunakan model problem based learning berbantuan media audio visual mengalami peningkatan secara signifikan. hal ini didukung dengan hasil observasi yang dilakukan oleh peneliti. berdasarkan analisis data dan hasil perhitungan uji hipotesis menggunakan regresi linier sederhana menunjukkan bahwa terdapat pengaruh pada penerapan problem based learning berbantuan media audiovisual terhadap hasil belajar peserta didik kelas IV SD Negeri 1 Sumberagung. berdasarkan hasil observasi, disimpulkan 
bahwa pembelajaran dengan menggunakan model problem based learning berbantuan media audio visual lebih menarik perhatian peserta didik dalam proses pembelajaran berlangsung, bahkan peserta didik menjadi lebih percaya diri dalam mengungkapkan jawaban-jawaban yang telah didiskusikan dengan kelompoknya. Berdasarkan hal tersebut, dapat diketahui bahwa terdapat pengaruh yang signifikan antara penerapan model problem based learning berbantuan media audio visual terhadap hasil belajar tematik peserta didik kelas IV SD Negeri 1 Sumberagung.

\section{KESIMPULAN}

Berdasarkan data hasil penelitian dan pembahasan diperoleh kesimpulan bahwa terdapat pengaruh pada penerapan model problem based learning berbantuan media audio visual terhadap hasil belajar tematik peserta didik kelas IV SD Negeri 1 Sumberagung. Hal tersebut berarti Ha dalam penelitian ini diterima yaitu terdapat pengaruh penerapan model problem based learning berbantuan media audio visual terhadap hasil belajar tematik peserta didik kelas IV SD Negeri 1 Sumberagung

Hasil penelitian ini disarankan kepada pendidik yang diharapkan mampu untuk melakukan inovasi dalam mengembangkan model pembelajaran yang inovatif, dapat memanfaatkan segala fasilitas sekolah sebagai alat bantu mengajar sehingga pembelajaran dapat terlaksana dengan sangat baik dan lebih kreatif dalam merancang dan mempersiapkan media pembelajaran yang inovatif dan menyenangkan bagi peserta didik. 


\section{DAFTAR PUSTAKA}

Budiningsih, Asri. 2012. Belajar dan Pembelajaran. Rineka Cipta, Jakarta.

Dewi, N. M. J., Putra, D. K. N. S., \& Ganing, N. N. 2017. Pengaruh Model Pembelajaran Problem Based Learning Berbantuan Media Audio Visual Animasi Terhadap Hasil Belajar IPA. Mimbar PGSD Undiksha, 5(2).

Ejin, S. 2016. Pengaruh Model Problem Based Learning (PBL Terhadap Pemahaman Konsep dan Keterampilan Berpikir Kritis Siswa Kelas IV SDN Jambu Hilir Baluti 2 Pada Mata Pelajaran Ilmu Pengetahuan Alam. JP (Jurnal Pendidikan): Teori dan Praktik, 1(1), 66-72.

Hikmi, dkk. 2018. Pengaruh Model PBL Dengan Media Audio Visual dan Laboratorium Riil Materi Asam Basa Terhadap Hasil Belajar. Jurnal Talenta Conference Series Science \& Technologi. 2: 290-292.

Jannah, A. R., Rahmawati, I., \& Reffiane, F. 2020. Keefektifan Model PBL Berbantu Media Audio-Visual Terhadap Hasil Belajar Tema Indahnya Keberagaman Di Negeriku. MIMBAR PGSD Undiksha, 8(3), 342-350.

Muhson, A. 2009. Peningkatan minat belajar dan pemahaman mahasiswa melalui penerapan problem-based learning. Jurnal Kependidikan: Penelitian Inovasi Pembelajaran, 39(2).

Muncarno. 2017. Statistika Penelitian Pendidikan. Hamim Group, Metro.

Paramartha, I. M. D., Suniasih, N. W., Negara, I. G. A. O., \& Ke, S. P. M. (2016). Pengaruh Model PBL Berbantuan Media Audio Visual Terhadap Penguasaan Kompetensi Pengetahuan IPA. Mimbar PGSD Undiksha, 4(1).

Purbarani, D. A., Dantes, N., \& Adnyana, P. B. (2018). Pengaruh Problem Based Learning Berbantuan Media Audio Visual Terhadap Kemampuan Berpikir Kritis Dan Hasil Belajar Ipa Di Sekolah Dasar. PENDASI: Jurnal Pendidikan Dasar Indonesia, 2(1), 24-34.

Susanto. 2013. Teori Belajar dan Pembelajaran. Kencana Prenada Media Group, Jakarta.

Umainalo, dkk. 2019. Problem Based Learning As An Effort To Improve Student Learning Outcomes. International Journal Of Scientific \& Technology Research.8:1140-1143.

Undang-undang Republik Indonesia Nomor 20 Tahun 2003 Tentang Sistem Pendidikan Nasional. 